ANUVA Volume 1 (1): 41-48, 2017

Copyright (C2017, ISSN: 2598-3040 online

Available Online at: http://ejournal.undip.ac.id/index.php/anuva

\title{
Repositori Institusi Universitas Diponegoro: Sebuah Analisis Webometrics
}

\author{
Yanuar Yoga Prasetyawan ${ }^{*}$ ) \\ ${ }^{1}$ Program Studi Ilmu Perpustakaan, Fakultas Ilmu Budaya, Universitas Diponegoro, \\ Jl. Prof. Soedarto, SH, Tembalang, Semarang.
}

${ }^{*}$ Korespondensi: yanuaryoga@live.undip.ac.id

\begin{abstract}
Webometric ranking is one of the indicators of college institution repository popularity in Indonesia. Diponegoro University through its institutional repository that can be accessed at http://eprints.undip.ac.id/ trying to pursue the best ranking from hundreds or even thousands of repositories in the world. This research presents quantitative data of Webometric calculation result of Repository Institution of Diponegoro University in 2016. The research method used is through 4 criteria of calculation ie size, file rich, visibility, and scholar. The result of the research showed that the criteria of page size Repository of Diponegoro University is 291.000 recall, then for file rich criteria there are 16,500 recall, then for scholar criteria 907 recall, while for visibility criteria based on graph presented by Magestic page SEO seems not enough backlinks that appear on every day.
\end{abstract}

Keywords: institutional repository; webometric; Diponegoro University

\begin{abstract}
Abstrak
Pemeringkatan Webometrik di Indonesia menjadi salah satu indikator pupolaritas repositori institusi perguruan tinggi. Universitas Diponegoro melalui repositori institusinya yang dapat diakses pada tautan http://eprints.undip.ac.id/ berupaya mengejar ranking terbaik dari ratusan bahkan ribuan repositori yang ada di dunia. Penelitian menyajikan data kuantitatif hasil perhitungan Webometrik Repositori Institusi Universitas Diponegoro pada tahun 2016. Metode Penelitian yang digunakan adalah melalui 4 kriteria perhitungan yaitu size, filerich, visibility, dan scholar. Hasil penelitian menunjukan bahwasanya pada kriteria size halaman Repositori Universitas Diponegoro adalah 291.000 recall (temuan), kemudian untuk kriteria filerich terdapat 16.500 recall (temuan), lalu untuk kriteria scholar 907 recall (temuan), sedangkan untuk kriteria visibility berdasarkan grafik yang dimunculkan oleh halaman Magestic SEO nampak belum cukup banyak backlink yang muncul pada tiap harinya.
\end{abstract}

Kata Kunci: repositori institusi; webometrik; universitas diponegoro

\section{Pendahuluan}

Bibliometrik merupakan pendekatan pengukuran komunikasi ilmiah yang digunakan sebagai alat untuk menganalisis dampak dari sebuah artikel yaitu sejauh mana artikel tersebut disitasi oleh artikel lain atau menganalisis produktifitas pengarang. Pendekatan pengukuran komunikasi ilmiah baru, juga diperkenalkan dengan istilah Webometrik. Jika Bibliometrik menganalisis sebuah artikel ilmiah atau pengarang, Webometrik menganalisis performa dari domain akademik (situs web perguruan tinggi). Webometrik membantu menjelaskan secara kuantitatif proses komunikasi ilmiah dengan fokus tidak pada database kutipan komersial seperti web of science (Thomson) dan scopus (Elsevier), tetapi pada informasi yang tersedia di website dan dapat diakses secara umum (public) (Aguillo, Ortega, Fernández, \& Utrilla, 2010; Aguillo, 2012; Björneborn \& Ingwersen, 2004; Jalal, Sutradhar, Sahu, Mukhopadhyay, \& Biswas, 2015; Thelwall, Mike and Vaughan, 2004). 
Tujuan dari analisis webometrik adalah untuk mempelajari berbagai aspek dari website termasuk struktur, organisasi, topologi, fungsi, karakteristik, interkoneksi, dan pengembangan halaman website (Noruzi, 2004). Meningkatkan situs web universitas dan web akademik berdasarkan indikator webometrik mengarah ke peningkatan perhatian yang lebih global dan membantu untuk mendapatkan peringkat dunia antar universitas yang lebih tinggi (Tafaroji, Tahamtan, Roudbari, \& Sedghi, 2014). The Ranking Web of World Repositories (http://repositories.webometrics.info) merupakan database yang dapat digunakan untuk melihat dampak komunikasi ilmiah repository institusi sebuah perguruan tinggi. Database tersebut dapat merangking dan mengurutkan repository institusi yang memiliki dampak paling tinggi sampai paling rendah. Rangking juga dapat dilihat pada tataran dunia maupun terbatas secara regional saja, tergantung kebutuhan penggunanya.

\section{Metode Penelitian}

Terdapat 4 kriteria penilaian yang digunakan untuk mengkalkulasi webometrik yaitu size, filerich, visibility, dan scholar (Aguillo et al., 2010). Ke-empat kriteria tersebut telah dijelaskan metode perhitungannya yang ditampilkaan pada halaman website The Ranking Web of World Repositories (http://repositories.webometrics.info), berikut penjelasan mengenai metode perhitungan analisis webometrik yang digunakan oleh penulis:

1. Size, Merupakan kriteria perhitungan dengan metode menghitung banyaknya halaman web yang muncul dari hasil recall yang dilakukan oleh search engine. Dalam tulisan ini search engine yang digunakan adalah Google. Teknik yang dilakukan penulis dalam memunculkan recall adalah dengan mengetikkan "site: eprints.undip.ac.id"

2. Visibility, Merupakan kriteria perhitungan dengan metode menghitung banyaknya external inlink (backlink) dari sebuah halaman website repository institusi yang diperolehnya dari Magestic SEO.

3. File Rich, Merupakan kriteria perhitungan dengan metode menghitung banyaknya file yang berformat teks seperti .pdf, .doc, .rtf, .xls, .ppt, dan .xml yang muncul dari hasil recall yang dilakukan oleh search engine. Teknik yang dilakukan penulis dalam memunculkan recall adalah dengan mengetikkan "site: eprints.undip.ac.id type file: .pdf"

4. Scholar, Merupakan kriteria perhitungan dengan metode menghitung banyaknya halaman web yang muncul dari hasil recall yang dilakukan oleh Google Scholar.

\section{Analisis dan Pembahasan}

Repositori Institusi UNDIP jika dilihat dari keempat kriteria penilaian tersebut, maka Repositori Institusi UNDIP secara regional nasional akan bertengger di posisi puncak, seperti pada gambar 1 berikut. 


\begin{tabular}{|c|c|c|c|c|c|c|}
\hline renkng & $\begin{array}{l}\text { Whint } \\
\text { tins }\end{array}$ & Insitule & slze & Malking & $\begin{array}{l}\text { Fits: } \\
\text { bicis }\end{array}$ & scacle: \\
\hline 1 & 1:2: & 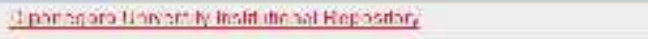 & $14 !$ & \%9 & $34 \mathrm{E}$ & *: \\
\hline s & $14 x$ & 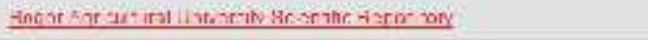 & (1) & $4 \varepsilon$ & ME & 14: \\
\hline 1 & 345 & Banatatra Liamara w Faros tor? & 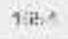 & sis & an & 8!: \\
\hline 1 & is & 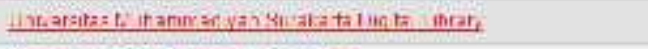 & Thit & ias & wi & 3 \\
\hline 3 & 322 & Towitata zale in ve Ith. Bezeslion & 128 & 012 & 535 & 32 \\
\hline 5 & 332 & 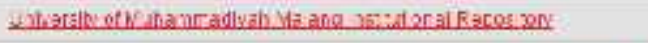 & $\varepsilon \wedge \varepsilon$ & 525 & 824 & $\Leftrightarrow$ \\
\hline i & sth & 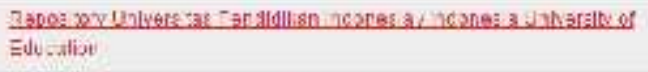 & 44 & 7:3.5 & triie & T:F \\
\hline s & 434 & 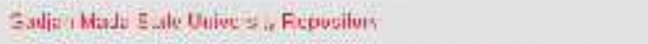 & 77 & 1027 & 872 & 17 \\
\hline 9 & 48 & 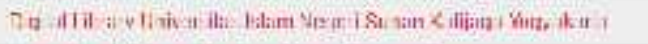 & E 1 +ी & 765 & 67? & רe \\
\hline 10 & 4h? & 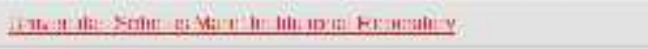 & Ait & 515 & ผรว & a: \\
\hline 11 & 400 & Hean icdin linivers z Hepasion, & w) & $3 \%$ & i $\mathrm{ic}$ & 133 \\
\hline 17 & 4h. & 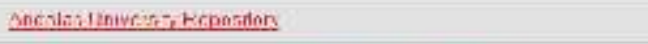 & AA & $2 a$ & 8i: & 286 \\
\hline $1 ; 3$ & a:s & 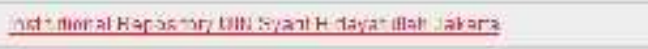 & atit & 10,12 & 19:3: & 14 \\
\hline 34 & iso & 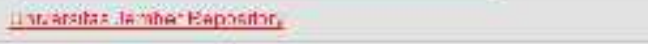 & 291 & $12 x+1$ & 1"ina: & 48 \\
\hline $1 \mathrm{~s}$ & iso & La:3LLtav UN Bhan Ancal & E18 & 1983 & 1us? & 253 \\
\hline
\end{tabular}

Gambar 1 Tampilan Halaman Website The Ranking Web of World Repositories

Setiap Repositori Institusi Perguruan Tinggi di Indonesia memiliki rangking yang berbeda untuk tiap kriterianya. Pada Tahun 2016 Repositori Institusi UNDIP untuk kriteria size berada di peringkat 405 dunia, visibility berada di peringkat 332 dunia, rich file berada di peringkat 43 dunia, dan scholar berada di peringkat 25 dunia. Namun jika dilihat dari peringkat nasional Repositori Institusi UNDIP untuk kriteria untuk kriteria size berada di peringkat 12 nasional, visibility berada di peringkat 2 nasional, rich file berada di peringkat 8 nasional, dan scholar berada di peringkat 2 nasional.

\subsection{Analisis Webometrik Repositori Universitas Diponegoro}

Melalui website The Ranking Web of World Repositories, pembaca telah disuguhi data peringkat repositori institusi dari peringkat teratas sampai terbawah hasil perhitungan website tersebut. Namun pembaca tidak dapat mengetahui berapa kuantitas hasil perhitungan yang dihasilkan oleh website tersebut. Dalam tulisan ini penulis mencoba melakukan perhitungan menggunakan metode analisis webometrik dengan mengacu pada 4 kriteria penilaian yang digunakan oleh website tersebut yaitu size, filerich, visibility, dan scholar.

Kriteria penilaian pertama adalah Size, kriteria perhitungannya dengan metode menghitung banyaknya halaman web yang muncul dari hasil recall yang dilakukan oleh search engine. Teknik yang dilakukan penulis dalam memunculkan recall adalah dengan mengetikkan "site: eprints.undip.ac.id" pada kolom pencarian di halaman google.com. melalui teknik tersebut dapat diketahui bahwasanya kuantitas Size halaman Repositori Universitas Diponegoro adalah 291.000 recall temuan, tampilan dapat dilihat pada gambar 2. Dengan teknik yang sama penulis mencoba membandingkan Size repositori milik Universitas Sumatera Utara, ditemukan recall sebanyak 623.000. Hal tersebut tidaklah mengherankan karena jika rangking tersebut disortir berdasarkan kriteria Size maka Repositori Universitas Sumatera Utara akan bertengger di urutan pertama nasional. 


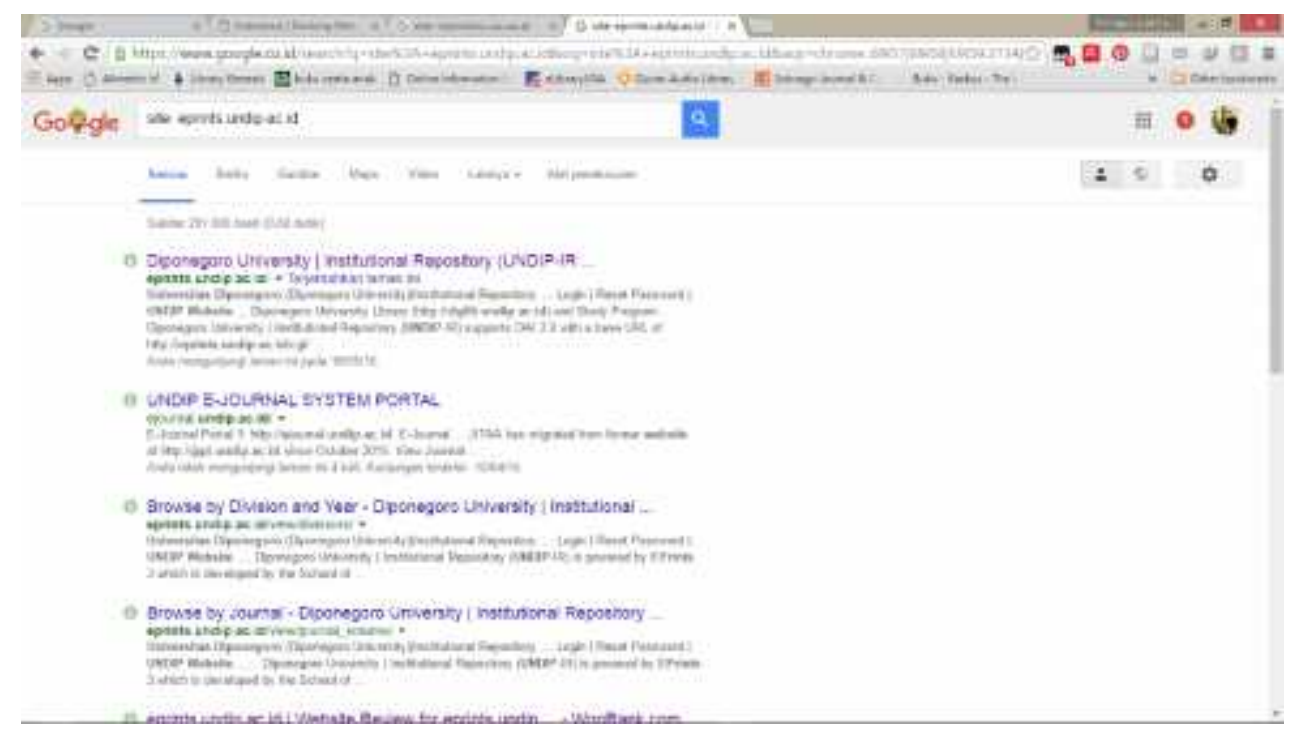

Gambar 2 Tampilan recall Size pada halaman Google

Namun yang perlu digaris bawahi adalah hasil recall tersebut tidak selalu menunjukan kuantitas yang sama pada tiap waktunya. Perihal tersebut dipengaruhi aktifitas institusi dalam menambah konten dan aktifitas halaman google dalam melakukan indeksasi. Sangat memungkinkan ketika penulis melakukan teknik yang sama namun di waktu yang berbeda, maka jumlah recall yang muncul akan bertambah atau bahkan berkurang. Proses perangkingan yang dilakukan oleh halaman website The Ranking Web of World Repositories tidak dilakukan setiap detik, menit, atau jam. Website tersebut memiliki periode perangkingan dalam waktu tertentu. Hasil perangkingan yang penulis tampilkan adalah perangkingan periode bulan Juli 2016.

Kriteria penilaian kedua adalah Visibility, yaitu merupakan kriteria perhitungan dengan metode menghitung banyaknya external inlink (backlink) dari sebuah halaman website repository institusi yang diperolehnya dari Magestic SEO. Backlink adalah salah satu indikator popularitas sebuah website (Jalal et al., 2015). Backlink adalah link yang diterima oleh setiap simpul (node) dari Website Repositori Universitas Diponegoro dari setiap simpul web. Simpul tersebut dapat berupa halaman web atau direktori atau situs web. Gambar 3 adalah grafik harian kemunculan backlink Website Repositori Universitas Diponegoro, Nampak dari gambar tersebut hampir pada setiap harinya terdapat kemunculan backlink walaupun tidak secara signifikan mengalami kenaikan atau penurunan kemunculan. Sedangkan pada grafik selanjutnya adalah grafik referring domain, yaitu domain dari mana backlink menunjuk ke halaman atau link website. Dalam grafik tersebut untuk Website Repositori Universitas Diponegoro nampak sedikit referring domain yang muncul pada setiap harinya. 


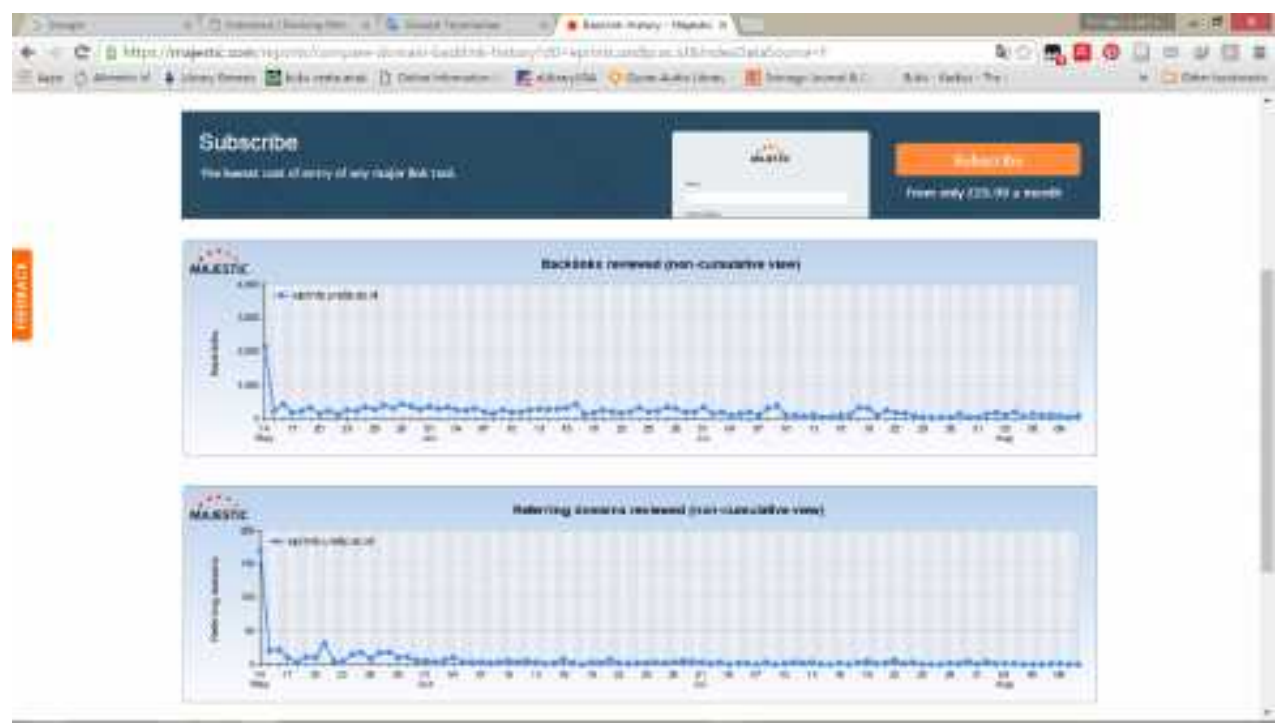

Gambar 3 Grafik Backlink History dari Referring Domain dan External Backlink

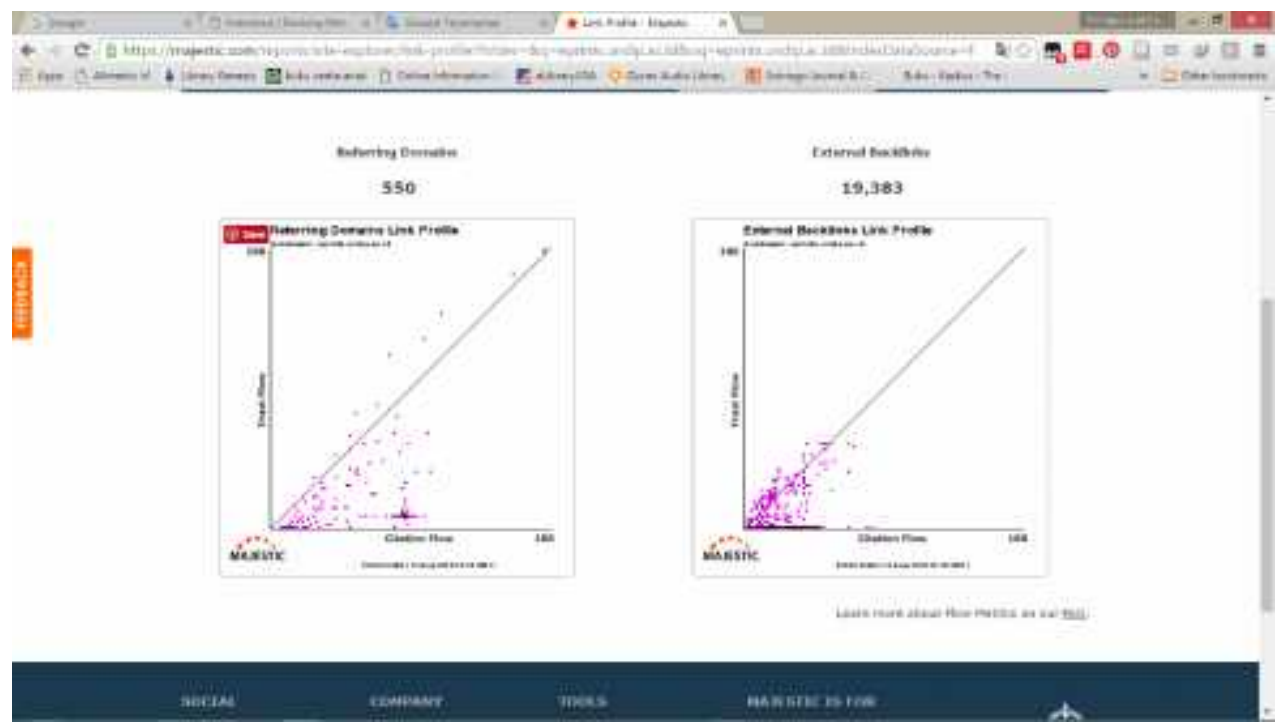

Gambar 4 Grafik Profil Referring Domain dan Profil External Backlink

Pada gambar 4 menunjukan grafik profil referring domain dan profil external backlink. Grafik tersebut menunjukan hubungan positif antara aliran kutipan (citation flow) dan aliran kepercayaan (trust flow) untuk kedua kasus profil tersebut. Aliran kutipan adalah metrik yang memprediksi pengaruh link di sebuah situs. Perihal tersebut tidak menilai kualitas link. Aliran kepercayaan menunjukkan dipercayainya sebuah link. Nilai aliran kepercayaan tergantung pada kualitas backlink. Jika aliran kepercayaan meningkat, aliran kutipan akan meningkat tetapi tidak sebaliknya (Jalal et al., 2015).

Kriteria penilaian ketiga adalah file rich, yaitu kriteria perhitungan dengan metode menghitung banyaknya file yang berformat teks seperti .pdf, .doc, .rtf, .xls, .ppt, dan .xml yang muncul dari hasil recall yang dilakukan oleh search engine. Teknik yang dilakukan penulis dalam memunculkan recall adalah dengan mengetikkan "site: eprints.undip.ac.id type file: .pdf" pada halaman Google, dalam tulisan ini 
penulis hanya menggali recall dengan tipe file ".pdf" saja karena mayoritas file yang diunggah oleh banyak repositori institusi adalah file berformat “.pdf”. Hasil dari teknik yang dilakukan penulis tersebut ditemukan recall sebanyak 16.500, tampilan hasil recall tersebut dapat dilihat pada gambar 5 .

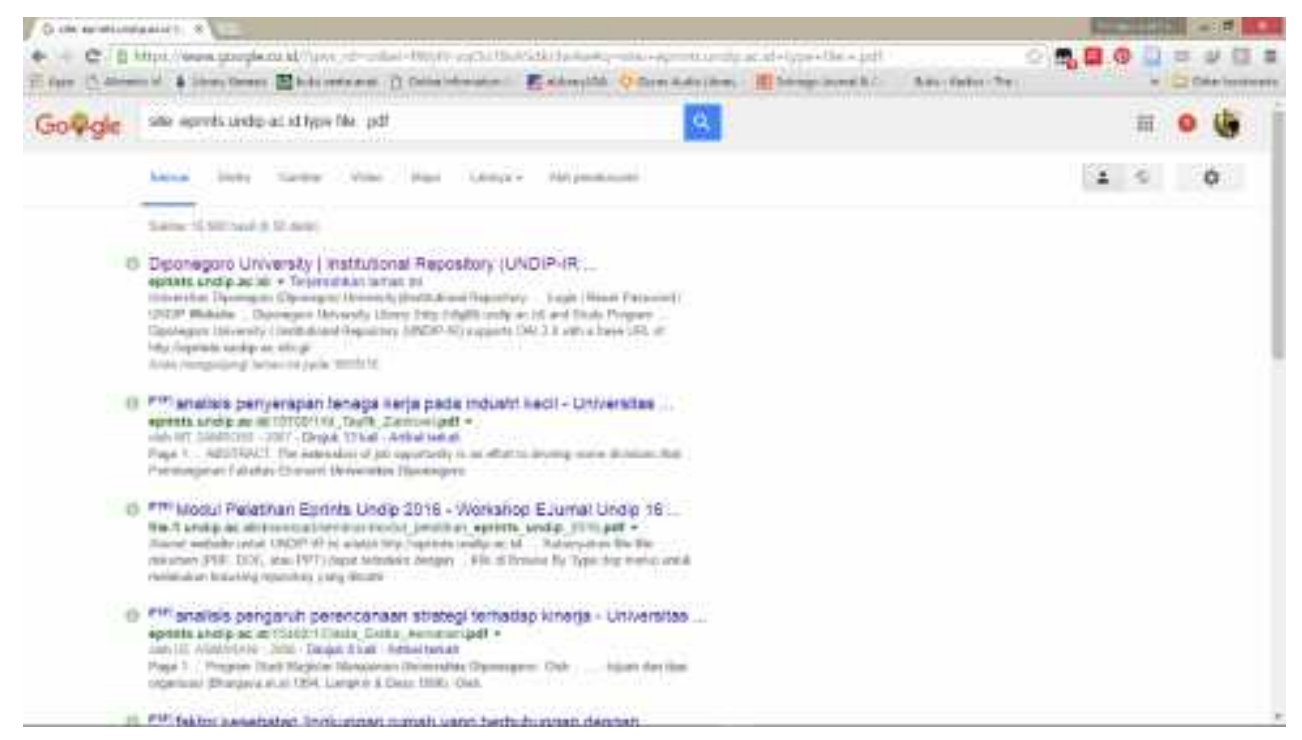

Gambar 5 Tampilan recall File Rich pada halaman Google

Google scholar adalah sebuah database bibliografi akademis yang tersedia secara gratis oleh raksasa mesin pencari Google. Google scholar telah diusulkan sebagai sumber daya database kutipan yang melengkapi sumber daya database kutipan komersial seperti web of science (Thomson) dan scopus (Elsevier) (Aguillo, 2012). Perihal tersebutlah yang menjadi alasan kenapa Google scholar menjadi salah satu kriteria yang cukup penting dalam perangkingan webometrik repository institusi.

Kriteria penilaian keempat adalah Scholar, merupakan kriteria perhitungan dengan metode menghitung banyaknya halaman web yang muncul dari hasil recall yang dilakukan oleh Google Scholar. Teknik yang dilakukan penulis adalah dengan mengetikkan "site: eprints.undip.ac.id" pada kolom penelusuran di halaman situs web scholar.google.com. Hasil dari penelusuran yang dilakukan diketemukan sebanyak 907 recall, tampilan hasil recall tersebut dapat dilihat pada gambar 6 .

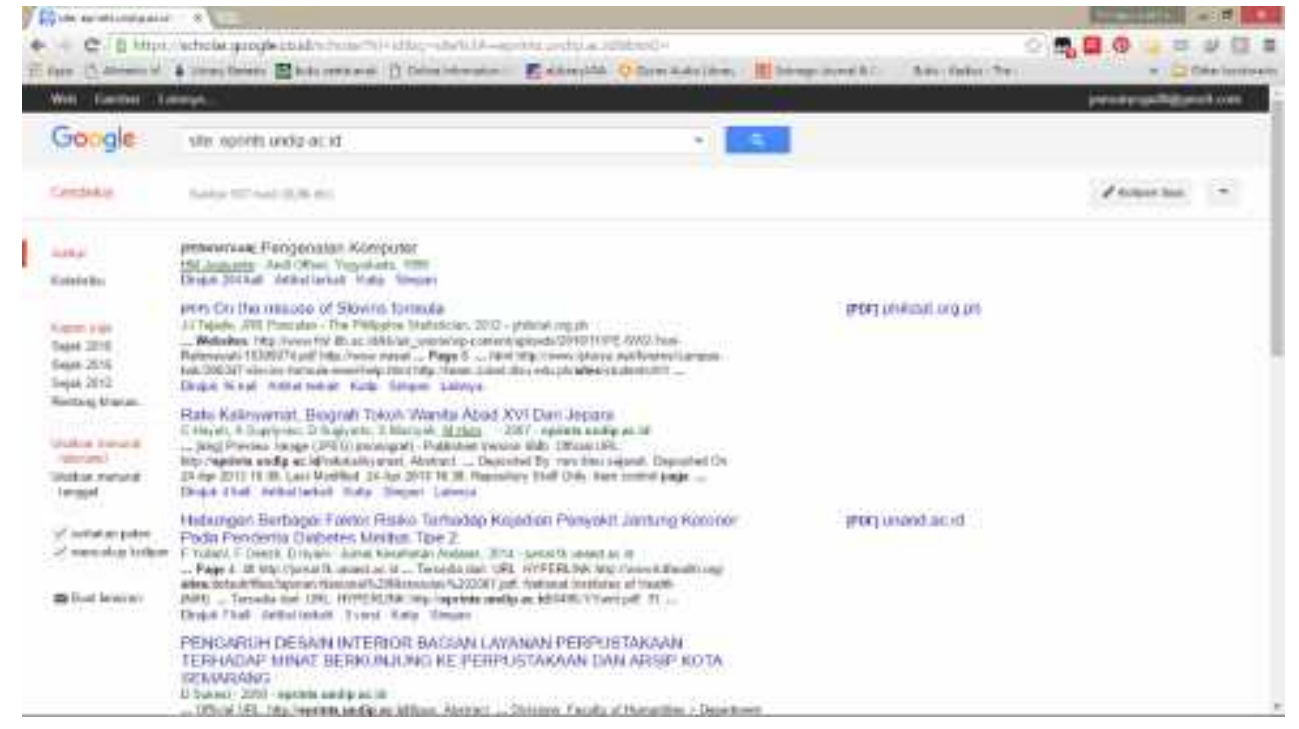

Gambar 6 Tampilan recall Scholar pada halaman Google Scholar 


\subsection{Urgensi Keterlibatan Perguruan Tinggi dalam Pengembangan Repositori Institusi Universitas Diponegoro}

Banyak penelitian terdahulu yang mengkawatirkan minimnya peran fakultas dalam usahanya turut mengumpulkan karya institusi yang akan disimpan dalam IR salah satunya dalam penelitian yang dilakukan oleh Bankier et.al (Bankier, Foster, \& Wiley, 2009). Namun tidak bagi Perpustakaan UNDIP, mereka memiliki keutungan dengan telah terintegrasikannya kegiatan wajib simpan pinjam karya institusi oleh civitas akademika sebagai syarat kelulusan mahasiswa. Untuk mempermudah pelaksananan pengumpulan karya institusi tersebut Perpustakaan UNDIP dibantu oleh sub perpustakaaan yang terdapat pada setiap fakultas. Perpustakan fakultas tersebut memiliki tugas dan kewajiban mengunggah karya institusi fakultasnya ke dalam IR UNDIP. IR UNDIP memiliki strategi khusus untuk menjaga rangking webometricsnya tetap bertengger diperingkat 1 nasional yaitu dengan menginstruksikan para uploder karya institusi tiap fakultas untuk memecah/ membagi tiap karya dalam pecahan bab dalam tugas akhir. Perihal tersebut menjaga salah satu unsur kriteria dalam perangkingan di webometrics yaitu visibilitas, semakin banyak backlink dalam sebuah IR maka peringkat visibilitasnya akan semakin tinggi. Namun yang masih menjadi kendala adalah belum semua fakultas di UNDIP melakukan hal tersebut, sehingga UNDIP harus puas duduk di peringkat kedua jika hanya dilihat dari peringkat visibilitasnya.

Dianugerahinya UNDIP pada tahun 2015 sebagai IR peringkat pertama nasional, peringkat pertama se-asia tenggara, peringkat ke tiga seasia, dan peringkat ke tujuh puluh sembilan dunia, tidak disia-siakan oleh Perpustakaan UNDIP untuk show up/memamerkan prestasinya kepada UNDIP pada khususnya dan kepada dunia pada umumnya dengan menampilkan label prestasi tersebut pada halaman utama (home page) IR UNDIP, tampilan tersebut nampak pada gambar 1. Perihal tersebut sesuai dengan rekomendasi dari Bankier et.al agar selalu menujukan kesuksesan dan keberhasilan dalam membangun IR agar senantiasa mendapatkan dukungan khusus dari universitas (Bankier et al., 2009; Bankier \& Smith, 2010). Meskipun terdapat penurunan ranking pada tahun 2016, namun pola yang sama masih dilakukan oleh IR UNDIP.

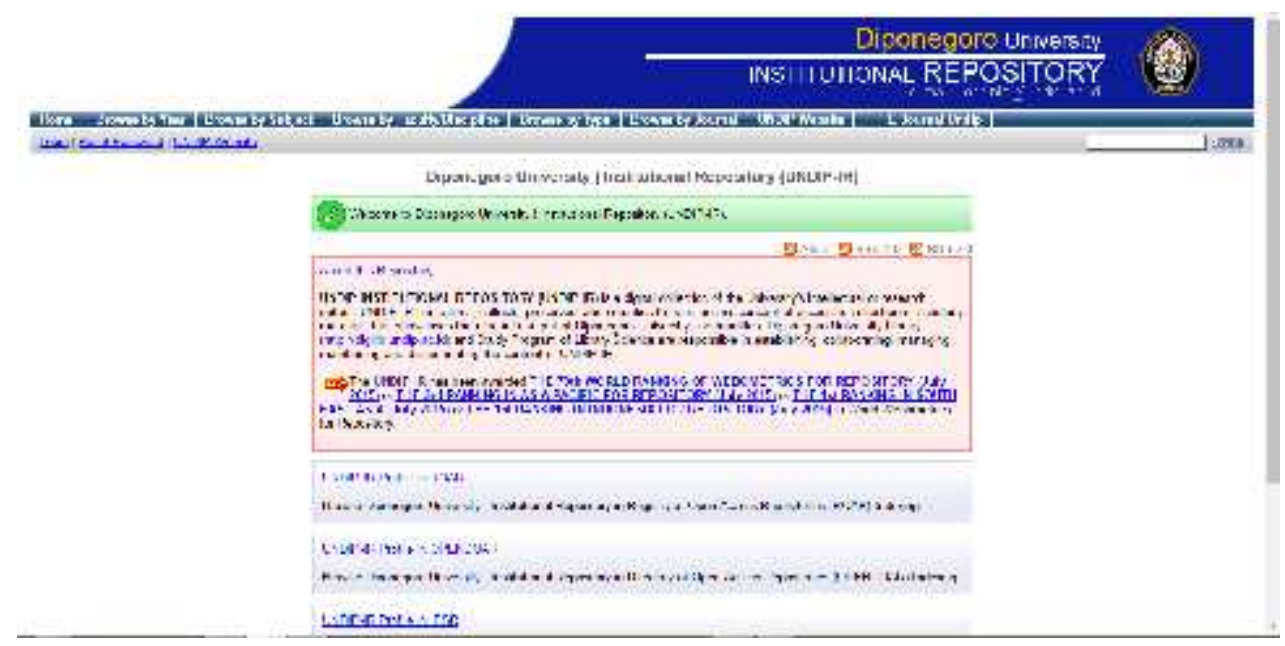

Gambar 7 Tampilan Homepage Repositori Institusional Universitas Diponegoro 


\section{Simpulan}

Repositori Institusi sangat penting dimiliki oleh sebuah institusi akademk. Melalui repository institusi sebuah institusi akademik mampu mempromosikan produktifitas akademisnya. Repositori Institusi juga memiliki dampak meningkatkan eksistensi dan visibilitas website institusi akdemik tersebut. Bertenggernya Institusional Repositori Universitas Diponegoro di puncak peringkat antar perguruan tinggi se Indonesia merupakan sebuah prestasi yang cukup membanggakan. Namun jika Institusional Repositori tersebut tidak dikelola dengan baik serta tidak mendapatkan perhatiaan yang lebih dari pengelola perpustakaan dan terlebih lagi para pemangku kebijakan, maka peringkat pertama tersebut akan hanya menjadi sejarah yang tidak mampu terulang kembali.

\section{Daftar Pustaka}

Aguillo, I. F. (2012). Is Google Scholar useful for bibliometrics? A webometric analysis. Scientometrics, 91(2), 343-351. http://doi.org/10.1007/s11192-011-0582-8

Aguillo, I. F., Ortega, J. L., Fernández, M., \& Utrilla, A. M. (2010). Indicators for a webometric ranking of open access repositories. Scientometrics, 82(3), 477-486. http://doi.org/10.1007/s11192-010-0183-y

Bankier, J.-G., Foster, C., \& Wiley, G. (2009). Institutional Repositories-Strategies for the Present and Future. The Serials Librarian, 56(1-4), 109-115. http://doi.org/10.1080/03615260802665423

Bankier, J.-G., \& Smith, C. (2010). Digital Repositories at a Crossroads : Achieving Sustainable Success through Campus-wide Engagement. In VALA2010 Conference Proceedings (pp. 1-18). Retrieved from http://works.bepress.com/jean_gabriel_bankier/8

Björneborn, L., \& Ingwersen, P. (2004). Toward a basic framework for webometrics. Journal of the American Society for Information Science and Technology, 55(14), 1216-1227. http://doi.org/10.1002/asi.20077

Jalal, S. K., Sutradhar, B., Sahu, K., Mukhopadhyay, P., \& Biswas, S. C. (2015). Search engines and alternative data sources in webometric research: An exploratory study. DESIDOC Journal of Library and Information Technology, 35(6), 427-435. Retrieved from http://www.scopus.com/inward/record.url?eid=2-s2.0-84948967924\&partnerID=tZOtx3y1

Noruzi, A. (2004). Introduction to Webology. Webology, 1(1). Retrieved from http://www.webology.org/2004/v1n1/a1.html

Tafaroji, R., Tahamtan, I., Roudbari, M., \& Sedghi, S. (2014). Webometric analysis of Iranian medical universities according to visibility, size and rich files. Webology, 11(1). Retrieved from http://www.scopus.com/inward/record.url?eid=2-s2.0-84906089399\&partnerID=tZOtx3y1

Thelwall, Mike and Vaughan, L. (2004). Webometrics: An introduction to the Special Issue. Journal of the American Society for Information Science and Technology, 55(14), 1213-1215. Retrieved from http://search.proquest.com/docview/231504961?accountid=49069 